\author{
Marquette University \\ e-Publications@Marquette
}

$2-2014$

\title{
Acrylamide Production Using Encapsulated Nitrile Hydratase from Pseudonocardia thermophila in a Sol-gel Matrix
}

Salette Martinez

Loyola University Chicago

Misty L. Kuhn

Loyola University Chicago

James T. Russell

Hamilton College - Clinton

Richard C. Holz

Marquette University, richard.holz@marquette.edu

Timothy E. Elgren

Hamilton College - Clinton

Follow this and additional works at: https://epublications.marquette.edu/chem_fac

Part of the Chemistry Commons

\section{Recommended Citation}

Martinez, Salette; Kuhn, Misty L.; Russell, James T.; Holz, Richard C.; and Elgren, Timothy E., "Acrylamide Production Using Encapsulated Nitrile Hydratase from Pseudonocardia thermophila in a Sol-gel Matrix" (2014). Chemistry Faculty Research and Publications. 295.

https://epublications.marquette.edu/chem_fac/295 
Marquette University

e-Publications@Marquette

\title{
Chemistry Faculty Research and Publications/College of Arts and Sciences
}

This paper is NOT THE PUBLISHED VERSION; but the author's final, peer-reviewed manuscript. The published version may be accessed by following the link in th citation below.

Journal of Molecular Catalysis B : Enzymatic, Vol. 100 (February 2014): 19-24. DOI. This article is (C) Elsevier and permission has been granted for this version to appear in e-Publications@Marquette. Elsevier does not grant permission for this article to be further copied/distributed or hosted elsewhere without the express permission from Elsevier.

\section{Acrylamide Production Using Encapsulated Nitrile Hydratase from Pseudonocardia thermophila in a Sol-gel Matrix}

\author{
Salette Martinez \\ Department of Chemistry and Biochemistry, Loyola University Chicago, Chicago, IL \\ Misty L. Kuhn \\ Department of Chemistry and Biochemistry, Loyola University Chicago, Chicago, IL \\ James T. Russell \\ Department of Chemistry, Hamilton College, Clinton, NY \\ Richard C. Holz \\ Department of Chemistry and Biochemistry, Loyola University Chicago, Chicago, IL \\ Department of Chemistry, Marquette University, Milwaukee, WI \\ Timothy E. Elgren \\ Department of Chemistry, Hamilton College, Clinton, NY
}

\section{Abstract}

The cobalt-type nitrile hydratase from Pseudonocardia thermophila JCM 3095 (PtNHase) was successfully encapsulated in tetramethyl orthosilicate sol-gel matrices to produce a PtNHase:sol-gel biomaterial. 
The PtNHase:sol-gel biomaterial catalyzed the conversion of $600 \mathrm{mM}$ acrylonitrile to acrylamide in $60 \mathrm{~min}$ at $35{ }^{\circ} \mathrm{C}$ with a yields of $>90 \%$. Treatment of the biomaterial with proteases confirmed that the catalytic activity is due to the encapsulated enzyme and not surface bound NHase. The biomaterial retained $50 \%$ of its activity after being used for a total of 13 consecutive reactions for the conversion of acrylonitrile to acrylamide. The thermostability and long-term storage of the PtNHase:sol-gel are substantially improved compared to the soluble NHase. Additionally, the biomaterial is significantly more stable at high concentrations of methanol ( $50 \%$ and $70 \%, \mathrm{v} / \mathrm{v}$ ) as a co-solvent for the hydration of acrylonitrile than native PtNHase. These data indicate that PtNHase:sol-gel biomaterials can be used to develop new synthetic avenues involving nitriles as starting materials given that the conversion of the nitrile moiety to the corresponding amide occurs under mild temperature and $\mathrm{pH}$ conditions.

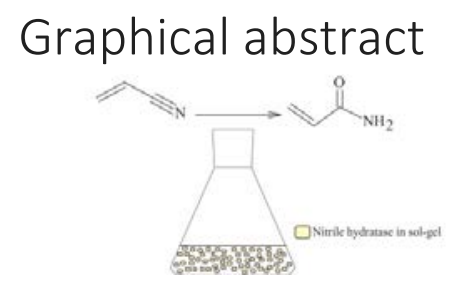

\section{Keywords}

Nitrile hydratase, Sol-gels, Enzyme immobilization, Biomaterials, Cobalt

\section{Introduction}

Nitriles are used extensively to produce a broad number of specialty chemicals containing amines, amides, amidines, carboxylic acids, esters, aldehydes, ketones, and heterocyclic compounds [1], [2]. These compounds are used in a wide array of reactions as chemical feedstocks for the production of solvents, extractants, pharmaceuticals, drug intermediates, pesticides (dichlobenil, bromoxynil, ioxynil, buctril), and polymers [1]. For example, acrylonitrile and adiponitrile are used in the production of polyacrylamide and nylon-66, respectively, the latter of which is one of the most important industrial polyamides derived from petroleum feedstocks [3], [4], [5], [6]. However, the harsh industrial conditions needed to hydrate nitriles to their corresponding amides (either acid or base hydrolysis), are often incompatible with the sensitive structures of many industrially and synthetically relevant compounds, which decreases product yields and consequently increases production costs [2], [4]. There are two metabolic pathways found in microorganisms for nitrile degradation (Scheme 1). In the first pathway, the nitrile is directly hydrolyzed to their corresponding carboxylic acid and ammonia by nitrilase (EC 3.5.5.1) [3]. In the second pathway, nitriles are first hydrated to their corresponding amide by nitrile hydratase (EC 4.2.1.84), then the amide is subsequently hydrolyzed to carboxylic acid and ammonia by amidase (EC 3.5.1.4) [3].

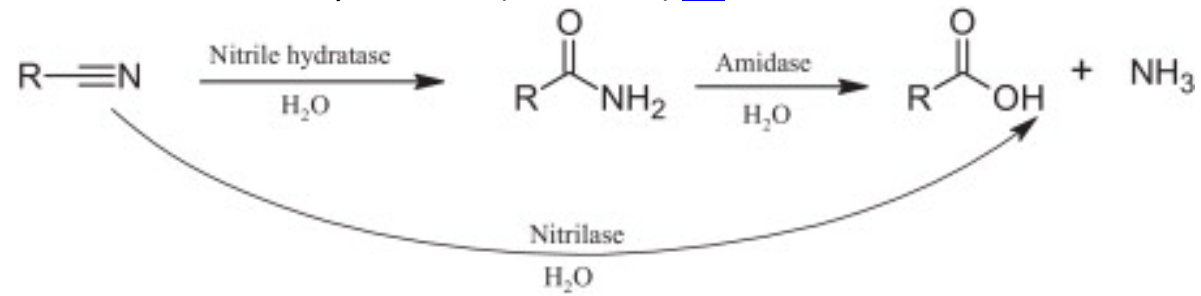

Scheme 1.

Microbial nitrile hydratase (NHase) has great potential as a biocatalyst for organic chemical processing because of its ability to convert nitriles to amides under physiological conditions. However a major issue in the use of enzymes, in general, and NHases specifically in organic synthetic processes is the difficulty in separating the enzyme from the synthetic reaction mixture [7]. A related issue involves the use of aprotic solvents in organic 
synthetic reaction mixtures, which renders most enzymes including NHase inactive [7], [8], [9]. One way to overcome both of these hurdles is through the encapsulation of enzymes within silica glasses derived through sol-gel processing [10], [11], [12], [13]. Encapsulated enzymes have resulted in the generation of novel functional materials that are optically transparent and sufficiently porous to permit small substrates access to the entrapped enzyme [11], [14], [15], [16], [17], [18], [19]. Recent studies have demonstrated that encapsulated proteins retain their solution structure and native function while residing in the hydrated pore of the sol-gel [11], [20], [21], [22]. Moreover, nanoscopic confinement within sol-gels stabilizes proteins against thermal and proteolytic degradation [11], [17]. These physical properties permit the broad application of solgel:protein materials as chemical sensors, separation media, and heterogeneous catalysts [23].

For industrial applications (i.e. acrylamide production) whole cells containing NHase and some isolated, purified, NHases have been immobilized on various supports by means of adsorption, entrapment, cross-linking, and membrane immobilization [4]. While the immobilization of whole cells containing NHase have been successful for the production of various commodity chemicals, purified NHases are necessary for the specific hydration of nitriles with other hydrolysable groups that will be susceptible to side-reactions within a bacterial cell. In addition, reaction systems that cannot tolerate carboxylate side products also require purified NHase since other enzymes in the bacterial nitrile degradation pathway, such as nitrilases can convert nitriles to carboxylates [24]. Purified enzymes also eliminate the need to have nitrile substrates pass across cell membranes; this would otherwise decrease the yields of recoverable products [4], [25]. Herein we report the immobilization of the Co-type NHase from Pseudonocardia thermophila JCM 3095 (PtNHase) using the sol-gel process in tetramethyl orthosilicate (TMOS) gels. This novel biocatalytic material is capable of specifically hydrating acrylonitrile to acrylamide in high yields and under mild conditions.

\section{Experimental}

\subsection{Materials}

Tetramethyl orthosilicate (TMOS, $\geq 99 \%$ ), acrylonitrile, acrylamide, Type I Trypsin from bovine pancreas, and Type II $\alpha$-chymotrypsin from bovine pancreas, were purchased from Sigma-Aldrich. All reagents were of the highest purity available and used as received without further purification.

\subsection{Plasmid construction}

A pUC18-NHase plasmid encoding the $\alpha$-subunit and $\beta$-subunit genes of PtNHase [26], [27], was used as a template for the polymerase chain reaction (PCR). A polyhistidine $\left(\mathrm{His}_{6}\right)$ affinity tag was engineered onto the $\mathrm{C}$ terminus of the $\alpha$-subunit gene using Phusion DNA polymerase. The following primers were used for the PCR: forward 5'-GCC ATG GGA AAC GGC GTG TAC GAC GTC GGC GG-3' and reverse 5'-GGT ACC AAG CTT TCA ATG ATG ATG ATG ATG ATG CGC GAC CGC CTT-3'. The PCR product ( $\beta \alpha-$ His $_{6}$ genes) was subcloned into the pSC-Bamp/kan vector using the Strataclone Blunt PCR cloning kit. The $\beta \alpha-\mathrm{His}_{6}$ genes were subsequently subcloned between the $\mathrm{NcOl}$ and HindIII restriction sites of the kanamycin resistant $\mathrm{pET} 28 \mathrm{a}^{+}$to create the Pt$\mathrm{His}_{6} / \mathrm{pET} 28 \mathrm{a}^{+}$plasmid. The nucleotide sequence for the PtNHase activator gene was obtained from the GeneBank, ID HV233497.1, and used to synthesize the gene with E. coli codon usage and cloned into a pIDTSMART (Integrated DNA Technologies, Inc.) ampicillin resistant vector with Ndel and HindIII restriction sites. Subsequently, the PtNHase activator gene was inserted between the Ndel and HindIII restriction sites of the ampicillin resistant $\mathrm{pET} 21 \mathrm{a}^{+}$vector to create the $P$ t-activator/pET21a ${ }^{+}$plasmid. All plasmid sequences were confirmed using the automated DNA sequencing at the University of Chicago Cancer Research Center DNA sequencing facility.

\subsection{Expression and purification of recombinant PtNHase}

The Pt-His ${ }_{6} / \mathrm{pET} 28 \mathrm{a}^{+}$and $\mathrm{Pt}$-activator/pET21a+plasmids were co-transformed into E. coli BL21(DE3) competent cells (Stratagene) for expression. A $100 \mathrm{~mL}$ LB-Miller starter culture was inoculated from a single colony with $50 \mu \mathrm{g} / \mathrm{mL}$ and $100 \mu \mathrm{g} / \mathrm{mL}$ of kanamycin and ampicillin, respectively. A $6 \mathrm{~L}$ culture was inoculated from this starter culture using $7 \mathrm{~mL}$ per liter and grown at $37^{\circ} \mathrm{C}$ until an $\mathrm{OD}_{600 \mathrm{~nm}}$ of $0.6-0.8$ was reached. The culture was 
cooled to $20^{\circ} \mathrm{C}$, induced with $0.1 \mathrm{mM}$ isopropyl $\beta$-d-1-thiogalactopyranoside (IPTG), supplemented with $0.25 \mathrm{mM} \mathrm{CoCl}_{2}$ [28], [29], and expressed at the same temperature for 16-18 $\mathrm{h}$. Cells were harvested by centrifugation at $6370 \times g 4{ }^{\circ} \mathrm{C}$, for $5 \mathrm{~min}$. The cells were resuspended at $3 \mathrm{~mL}$ per gram of buffer $\mathrm{A}$ ( $50 \mathrm{mM}$ $\mathrm{NaH}_{2} \mathrm{PO}_{4}, \mathrm{pH} 7.5,500 \mathrm{mM} \mathrm{NaCl}, 10 \mathrm{mM}$ imidazole) then lysed by sonication on ice for $8 \mathrm{~min}$ (30 s on, $45 \mathrm{~s}$ off) using a 21W Misonex sonicator 3000 . Cell debris was removed by two rounds of centrifugation at $31,000 \times g$, $4{ }^{\circ} \mathrm{C}$, for $20 \mathrm{~min}$. The protein was purified by immobilized metal affinity chromatography (IMAC) using Ni-NTA (nickel-nitrilotriacetic acid) Superflow Cartridges (Qiagen). The column was equilibrated with buffer $A$ and the crude extract was loaded onto the column. Unbound protein was washed with 15 column volumes (CV) of buffer A with $25 \mathrm{mM}$ imidazole. The protein was eluted with a linear gradient (0-100\%) of buffer B (buffer A with $500 \mathrm{mM}$ imidazole) over $20 \mathrm{CVs}$ at a flow rate of $2 \mathrm{~mL} / \mathrm{min}$. Peak fractions were pooled, resuspended in buffer $\mathrm{C}$ (50 mM Tris- $\mathrm{HCl} \mathrm{pH} \mathrm{7.5,} 300 \mathrm{mM} \mathrm{NaCl}$ ) and concentrated with an Amicon Ultra-15 centrifugal filter device with a molecular weight cutoff (MWCO) of 30,000 (Millipore). The purity of PtNHase was analyzed by using $12.5 \%$ SDS-PAGE. The protein concentration was determined by UV absorbance at $280 \mathrm{~nm}$ using a calculated molar extinction coefficient of 174, $640 \mathrm{M}^{-1} \mathrm{~cm}^{-1}$ and the Coomassie (Bradford) Protein Assay Kit (Thermo Scientific Pierce). The calculated molecular mass of the heterotetramer was $101 \mathrm{kDa}$. Theoretical molecular mass and protein extinction coefficients were calculated with the ExPASy ProtParam tool [30].

\subsection{Kinetic characterization of PtNHase}

The activity of purified PtNHase was determined by measuring the hydration of $100 \mathrm{mM}$ acrylonitrile to acrylamide $\left(225 \mathrm{~nm}, \varepsilon=2.9 \mathrm{mM}^{-1} \mathrm{~cm}^{-1}\right)$ in $50 \mathrm{mM}$ Tris- $\mathrm{HCl}, \mathrm{pH} 7.5$ at $35^{\circ} \mathrm{C}$. Assays were performed in a $1 \mathrm{~mL}$ quartz cuvette in triplicate on a Shimadzu UV-2450 PC spectrophotometer equipped with a TCC temperature controller. One unit of enzyme activity was defined as the amount of enzyme that catalyzed the production of $1 \mu \mathrm{mol}$ of acrylamide per minute at $35^{\circ} \mathrm{C}$.

\subsection{Encapsulation of PtNHase in tetramethyl orthosilicate}

The sol consisted of $1.57 \mathrm{~mL}$ of TMOS, $0.350 \mathrm{~mL}$ Nanopure $(18 \Omega) \mathrm{H}_{2} \mathrm{O}$, and $0.011 \mathrm{~mL}$ of $0.040 \mathrm{M} \mathrm{HCl}$. The mixture was sonicated on ice for $30 \mathrm{~min}$, and then left on ice for $\sim 1 \mathrm{~h}$ prior to protein incorporation. Hydrolyzed TMOS sol $(0.100 \mathrm{~mL})$ was mixed with an equal volume of pure PtNHase $(1.8 \mathrm{mg})$ in $50 \mathrm{mM}$ Tris $-\mathrm{HCl}, \mathrm{pH} 7.5$, $300 \mathrm{mM} \mathrm{NaCl}$. The mixture was placed on ice until gelation occurred to create PtNHase:sol-gel monoliths at the bottom of a glass vial. Following gelation, the monoliths were washed three times with $0.400 \mathrm{~mL}$ of $50 \mathrm{mM}$ Tris$\mathrm{HCl}$, pH 7.5 (sol-gel buffer) and stored at $4{ }^{\circ} \mathrm{C}$ overnight in $0.400 \mathrm{~mL}$ of the same buffer. The following day, the aged monoliths were crushed to produce a heterogeneous material and then washed three times with $0.400 \mathrm{~mL}$ of the sol-gel buffer. The buffer used to age the PtNHase:sol-gels and buffer from the wash were tested for protein leaching by the Coomassie (Bradford) Protein Assay Kit (Pierce).

\subsection{Kinetic characterization of the PtNHase:sol-gel}

The activity of the PtNHase:sol-gel biomaterial was determined by measuring the conversion of acrylonitrile to acrylamide using high performance liquid chromatography (HPLC). A $5 \mathrm{~mL}$ solution of $600 \mathrm{mM}$ acrylonitrile in $50 \mathrm{mM}$ Tris- $\mathrm{HCl} \mathrm{pH} 7.5$ at $35^{\circ} \mathrm{C}$ was reacted with PtNHase:sol-gel biomaterial with constant shaking at $250 \mathrm{rpm}$. Aliquots of the reaction mixture $(0.300 \mathrm{~mL})$ were taken at fixed-time intervals and analyzed by HPLC using a Shimadzu Shim-Pack XR-ODS C18 reverse-phase column $(3.0 \mathrm{~mm}$ i.d. $\times 75 \mathrm{~mm})$ with a mixture of $97 \%$ water: $3 \%$ methanol as the mobile phase at $220 \mathrm{~nm}$. The specific activity $(\mathrm{U} / \mathrm{mg})$ of the PtNHase:sol-gel biomaterial was calculated from the reaction rate $(\mathrm{mmol} / \mathrm{L} / \mathrm{min})$, the amount of the PtNHase encapsulated, and the volume of the reaction. The concentration of acrylamide produced was determined using standard curves of peak area versus known acrylamide concentrations.

\subsection{Recycling experiments}

A $5 \mathrm{~mL}$ solution of $600 \mathrm{mM}$ acrylonitrile in $50 \mathrm{mM}$ Tris- $\mathrm{HCl} \mathrm{pH} 7.5$ at $35^{\circ} \mathrm{C}$ was reacted with PtNHase:sol-gel biomaterial for $1 \mathrm{~h}$ after which an aliquot $(0.300 \mathrm{~mL})$ was taken for HPLC analysis. The product mixture was then decanted and the hydrogel washed with $1.2 \mathrm{~mL}$ of sol-gel buffer. The PtNHase:sol-gel hydrogel was resuspended in $5 \mathrm{~mL}$ of $600 \mathrm{mM}$ acrylonitrile in $50 \mathrm{mM}$ Tris $-\mathrm{HCl} \mathrm{pH} 7.5$ at $35^{\circ} \mathrm{C}$ and the reaction repeated as described above. This process of reacting, recovering, washing, and re-suspending the PtNHase:sol-gel hydrogel 
was repeated 12 additional times resulting in 12 separate cycles with the same sample of the PtNHase:sol-gel biomaterial.

\subsection{Proteolytic digestion of soluble and PtNHase:sol-gels}

Trypsin digestion of soluble $(0.5 \mathrm{mg})$ PtNHase and PtNHase:sol-gel material (1.8 $\mathrm{mg}$ of PtNHase) was performed at a ratio of 1:1 (trypsin:PtNHase) in $50 \mathrm{mM}$ Tris- $\mathrm{HCl}$ and $1 \mathrm{mM} \mathrm{CaCl}, \mathrm{pH} 7.6$ (trypsin reaction buffer) at $35^{\circ} \mathrm{C}$ for $18 \mathrm{~h}$ with constant agitation. The $\alpha$-chymotrypsin digestion of soluble PtNHase $(0.5 \mathrm{mg})$ and PtNHase:sol-gel material (1.8 mg of PtNHase) was performed in $100 \mathrm{mM}$ Tris- $\mathrm{HCl}$ and $10 \mathrm{mM} \mathrm{CaCl}, \mathrm{pH} 8.0$ ( $\alpha$-chymotrypsin buffer), also at a $1: 1$ ratio ( $\alpha$-chymotrypsin:PtNHase) at $35^{\circ} \mathrm{C}$ for $18 \mathrm{~h}$ with constant agitation. Along with the digestion samples, controls that consisted of PtNHase in trypsin and $\alpha$-chymotrypsin reaction buffers were also incubated at $35^{\circ} \mathrm{C}$ for $18 \mathrm{~h}$ with constant agitation. Following digestion, the degraded samples of soluble PtNHase and controls were centrifuged, cooled on ice, and assayed for PtNHase activity using the assay conditions described above. The activity of the control samples was taken as $100 \%$. The PtNHase:sol-gels were thoroughly washed three times with $0.400 \mathrm{~mL}$ of sol-gel buffer to remove trypsin or $\alpha$-chymotrypsin and digestion products. Then the PtNHase:sol-gel hydrogels were assayed for catalytic using the standard assay conditions.

\subsection{Activity of soluble and encapsulated PtNHase in organic co-solvents}

The activity of the soluble PtNHase with 50, 70, and $100 \%$ (v/v) methanol as the organic co-solvent toward acrylonitrile was measured spectrophotometrically at $25{ }^{\circ} \mathrm{C}$ as described above. Each measurement was repeated at least three times. The hydration of acrylonitrile using the PtNHase:sol-gel hydrogels with organic co-solvents at $50 \%, 70 \%$ and $100 \%(\mathrm{v} / \mathrm{v})$ was carried out in $5 \mathrm{~mL}$ reactions of $600 \mathrm{mM}$ acrylonitrile at $25^{\circ} \mathrm{C}$ with constant shaking $(250 \mathrm{rpm})$. Aliquots, $0.300 \mathrm{~mL}$, of the reaction mixture were taken at fixed-time intervals and analyzed by HPLC as described above.

\subsection{Thermostability of the soluble and immobilized PtNHase}

The thermostability of soluble PtNHase and PtNHase:sol-gel biomaterial was determined by incubation at 50, 60,70 , and $80^{\circ} \mathrm{C}$ for $0,30,60,180,300,420$, and $600 \mathrm{~min}$. After the incubation period was completed, the residual enzyme activity of the samples was determined using the assay conditions described above.

\section{Results and discussion}

\subsection{Encapsulation of PtNHase}

Engineering of a hexa-histidine tag allowed for the isolation of $\sim 10 \mathrm{mg}$ per liter of culture of pure PtNHase (Fig. 1) using a single purification step. Purified PtNHase was then used for encapsulation in tetramethylorthosilicate (TMOS) gels using the sol-gel method. Analysis of both the buffer in which the monoliths were stored and the buffer from all the washing steps using the Bradford assay indicated that on average $<0.5 \%$ of the PtNHase protein was present in both the wash buffer and the storage buffer. These data indicate that $\sim 99.5 \%$ of the protein is encapsulated within the sol-gel matrix.

$\mathrm{MW}, \mathrm{kDa}$

97.4

66.2

45.0

$\beta$

31.0

$\alpha$ 
Fig. 1. SDS-PAGE of purified PtNHase. Lane 1 purified PtNHase and lane 2 molecular weight standards.

Under solution conditions, PtNHase catalyzes the hydration of acrylonitrile at $\mathrm{pH} 7.5$ and $25^{\circ} \mathrm{C}$ with a $k_{\text {cat }}$ value of $1460 \pm 90 \mathrm{~s}^{-1}$ and a $K_{\mathrm{m}}$ value of $1.3 \pm 0.3 \mathrm{mM}$. Interestingly, non-proteolytically digested PtNHase:sol-gel biomaterial react readily with acrylonitrile (Fig. 2) at $35^{\circ} \mathrm{C}$ in $50 \mathrm{mM}$ Tris $-\mathrm{HCl} \mathrm{pH} 7.5$ with $>90 \%$ conversion of $600 \mathrm{mM}$ acrylonitrile to acrylamide in $60 \mathrm{~min}$. These data indicate that the kinetics of substrate turnover for solgel encapsulated NHases appear to be governed by mass transport of the substrate through the porous gel to the enzyme active site and product release. The reaction mixture was analyzed by high-performance-liquid chromatography (HPLC) and no acrylic acid was detected indicating that only the desired product, acrylamide, was produced. Quantitating the reaction of acrylonitrile with PtNHase:sol-gel biomaterials is difficult as the exact quantity of encapsulated enzyme is not known, however, assuming that $\sim 99.5 \%$ of the enzyme used was encapsulated at least $12 \%$ of the solution state activity is retained at $35^{\circ} \mathrm{C}$. Protein denaturation or inaccessibility to enzyme buried within the sol-gel material likely results in reduced activity upon encapsulation of the enzyme. Even so, these biomolecular nanocomposites display the expected enzymatic properties including substrate recognition as NHases in solution.

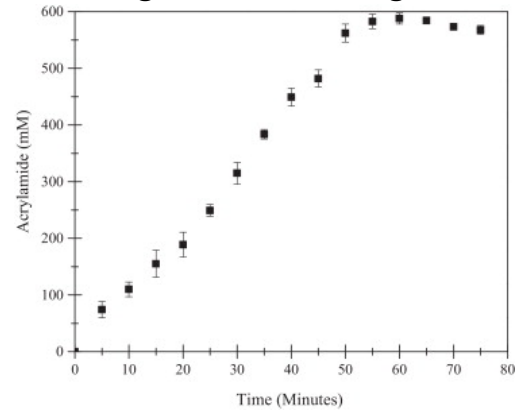

Fig. 2. Time course for the hydration of $600 \mathrm{mM}$ acrylonitrile to acrylamide in $50 \mathrm{mM}$ Tris $-\mathrm{HCl} \mathrm{pH} 7.5$ at $35^{\circ} \mathrm{C}$ using PtNHase:sol-gels containing $1.8 \mathrm{mg}$ of PtNHase.

\subsection{Proteolytic digestion of soluble PtNHase and PtNHase:sol-gel biomaterial}

To ensure that substrate has access to fully encapsulated enzyme and not simply protein adhered to the surface, the PtNHase:sol-gel biomaterial was treated with trypsin or $\alpha$-chymotrypsin to proteolytically digest all surface accessible protein. Interestingly, the PtNHase:sol-gel biomaterial retained $>90 \%$ of its residual activity after digestion with either trypsin or $\alpha$-chymotrypsin (Fig. 3) while soluble PtNHase retained $<15 \%$ of its residual activity after digestion, indicating that surface bound enzyme is hydrolyzed, but interior PtNHase is not. These data also indicate that substrate has access to the PtNHase enzyme trapped in the interior of the sol-gel biomaterial, which is an active catalyst but protected from proteolytic digestion.

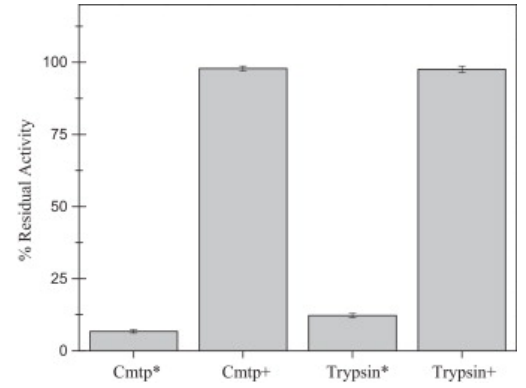

Fig. 3. Residual activity of soluble PtNHase $(*)$ and PtNHase:sol-gels $(+)$ proteolytically digested with $\alpha$ chymotrypsin (Cmtp) and trypsin. The soluble PtNHase $\left({ }^{*}\right)$ and PtNHase:sol-gels $(+)$ were incubated at a 1:1 ratio of enzyme:protease for $18 \mathrm{~h}$ at $35^{\circ} \mathrm{C}$. Residual activity was measured with $100 \mathrm{mM}$ (soluble PtNHase) and $600 \mathrm{mM}$ (PtNHase:sol-gels) acrylonitrile in $50 \mathrm{mM}$ Tris- $\mathrm{HCl} \mathrm{pH} 7.5$ at $35^{\circ} \mathrm{C}$.

\subsection{Thermostability of soluble PtNHase and PtNHase:sol-gel biomaterial}

The thermostability of soluble PtNHase enzyme and the PtNHase:sol-gel biomaterial was evaluated over a temperature range of $50-80^{\circ} \mathrm{C}$. Both soluble PtNHase enzyme and PtNHase:sol-gel biomaterial were highly stable at $50^{\circ} \mathrm{C}$ over $600 \mathrm{~min}$ incubation (Fig. 4). At $60^{\circ} \mathrm{C}$, the stability of the soluble PtNHase enzyme decreases 
significantly after 30 min of incubation (Fig. 4A); however, the PtNHase:sol-gel biomaterial showed greater stability at this temperature (Fig. 4B). The PtNHase:sol-gel biomaterial also showed improved stability after incubation at $70^{\circ} \mathrm{C}$ compared to the soluble enzyme (Fig. 4B). Interestingly, neither the soluble enzyme nor the biomaterials were stable when incubated at $80^{\circ} \mathrm{C}$. Based on published studies that have looked at the thermostability of soluble vs. encapsulated enzymes [17], [31], [32], we hypothesized that the observed improvement in thermostability of the enzyme upon the encapsulation in the sol-gel matrix is due to the enzyme being in a conformation that prevents unfolding and thus its denaturation at high temperatures.

A.

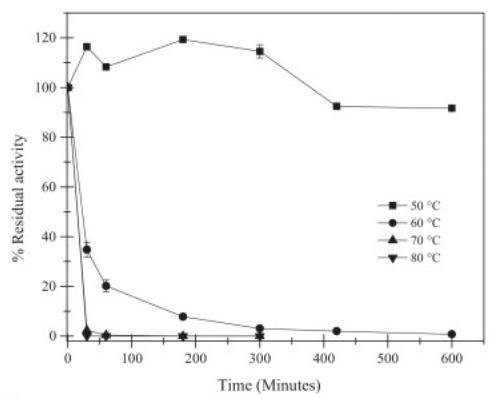

B.

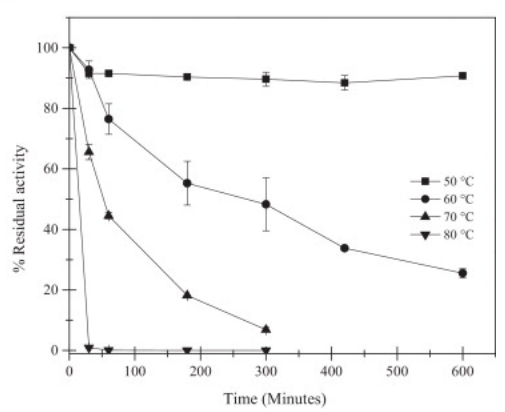

Fig. 4. Thermostability of soluble PtNHase (A) and PtNHase:sol-gels (B). The residual activity of the soluble and encapsulated after the high temperature incubation was determined by measuring the hydration of acrylonitrile to acrylamide at $35^{\circ} \mathrm{C}$.

\subsection{Reusability and long-term stability of the PtNHase:sol-gel biomaterial}

For commercial applications, a biocatalyst must be reusable and have long-term stability [33]. With this in mind we sought to investigate whether the PtNHase:sol-gel biomaterial could be recycled in subsequent reactions with acrylonitrile. After every use, the PtNHase:sol-gel biomaterial was thoroughly washed with buffer to remove residual acrylonitrile and acrylamide then submitted to the same reaction conditions (Fig. 5 ). The conversion of acrylonitrile to acrylamide decreases linearly with $\sim 50 \%$ of the initial activity remaining after thirteen cycles. Remarkably, the PtNHase:sol-gel biomaterial can also be stored at $4{ }^{\circ} \mathrm{C}$ in buffer and used weeks later without significant loss of activity ( $\underline{\text { Fig. } 6}$ ). Thus, encapsulation of PtNHase provides enhanced stability providing a biomaterial that can be recycled multiple times, stored, and reused.

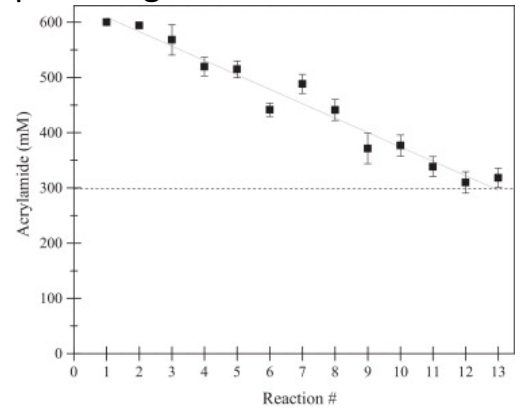

Fig. 5. Production of acrylamide using recycled PtNHase:sol-gels. Each reaction consisted of $600 \mathrm{mM}$ acrylonitrile in $50 \mathrm{mM}$ Tris- $\mathrm{HCl} \mathrm{pH} 7.5$ at $35^{\circ} \mathrm{C}, 1 \mathrm{~h}$. 


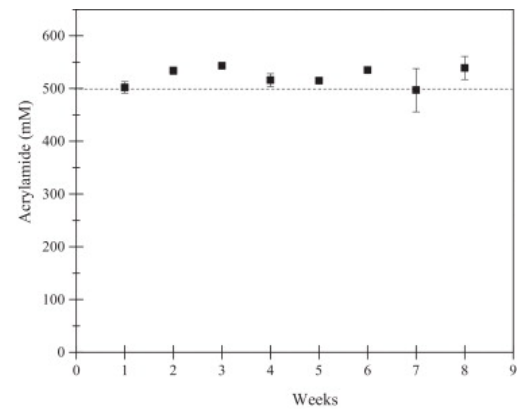

Fig. 6. Long-term stability of the PtNHase:sol-gels. The PtNHase:sol-gel hydrogels were used for the hydration of $600 \mathrm{mM}$ acrylonitrile in $50 \mathrm{mM}$ Tris- $\mathrm{HCl} \mathrm{pH} 7.5$ at $35^{\circ} \mathrm{C}, 1 \mathrm{~h}$.

\subsection{Stability of the soluble PtNHase and PtNHase:sol-gel biomaterial in organic co- solvent}

Typically, the solubility of nitriles at high concentrations becomes problematic requiring organic solvents; however, enzymes often denature in organic solvents. Remarkably, the PtNHase:sol-gel biomaterial placed in methanol is able to hydrolyze acrylonitrile to acrylamide. Since only one mole of water is consumed in each catalytic cycle, enough water may exist in the sol-gel or in the methanol to allow the encapsulated enzyme to remain catalytic. Therefore, we examined the hydration of acrylonitrile in 90:10 (data not shown), 70:30 and 50:50 MeOH:water solvent mixtures (Fig. 7). Greater than $90 \%$ conversion of acrylonitrile to acrylamide was achieved in 50:50 MeOH:water solvent mixtures while 75\% conversion was achieved in 70:30 MeOH:water solvent mixtures. For comparison purposes, soluble PtNHase exhibits only 65\% of its native activity in 50:50 $\mathrm{MeOH}$ :water solvent mixtures which decreases to $15 \%$ in 70:30 MeOH:water solvent mixtures (Fig. 7). Therefore, sol-gel encapsulation clearly affords significant stabilization against increasing protic solvent concentrations, compared to the enzyme solutions.

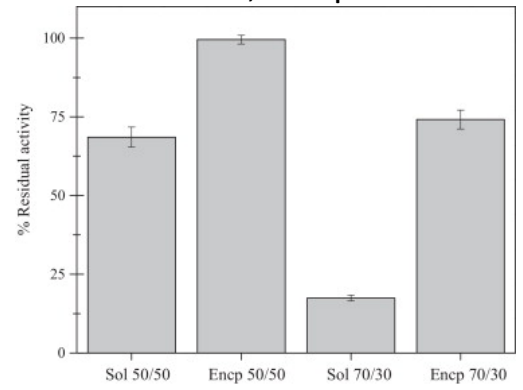

Fig. 7. Residual activity of the soluble (Sol) and encapsulated (Encp) PtNHase for the conversion of acrylonitrile to acrylamide in a solution of 50/50 and $70 / 30 \mathrm{MeOH} /$ water.

\section{Conclusions}

In summary, in this work we present the first encapsulation of a nitrile hydratase in a sol-gel matrix. The resulting biomaterial (PtNHase:sol-gel) exhibits catalytic activity toward acrylonitrile providing only the acrylamide as the product. Although the activity of the encapsulated PtNHase is diminished compared to the soluble PtNHase, its thermal stability is markedly improved. The hydrogels were active and stable when exposed to proteases and the enzyme could withstand protic solvent mixtures. Additionally, PtNHase:sol-gel biomaterials were successfully used and recycled for the hydration of $600 \mathrm{mM}$ acrylonitrile to acrylamide and remained active for more than 8 weeks at $4^{\circ} \mathrm{C}$. The beauty of NHase biocatalytic materials as organic synthetic tools resides in the fact that the NHase:sol-gel materials can be cast into any shape desired and if cast as pellets, can be added in a catalytic amount to a reaction mixture and simply filtered or decanted off after a prescribed reaction time. Moreover, these materials will potentially provide functional biomaterials capable of hydrolyzing nitriles in a chemo, regio, and stereoselective manner from a wide variety of nitrile substrates thus, providing synthetic chemists new avenues to design synthetic methodologies using nitriles as starting materials. 


\section{Acknowledgments}

This work was supported by the National Science Foundation ( $\mathrm{CHE}-1058357, \mathrm{RCH})$ and the Petroleum Research Fund (ACS PRF 50033-ND4, RCH). The authors gratefully acknowledge Dr. Miguel A. Ballicora and Gregory Rahn for assistance with HPLC.

\section{References}

[1] A. Banerjee, R. Sharma, U.C. Banerjee. Appl. Microbiol. Biotechnol., 60 (2002), pp. 33-44

[2] M.-X. Wang. Top. Catal., 35 (2005), pp. 117-130

[3] S. Prasad, T.C. Bhalla. Biotechnol. Adv., 28 (2010), pp. 725-741

[4] H. Velankar, K.G. Clarke, R.d. Preez, D.A. Cowan, S.G. Burton. Trends Biotechnol., 28 (2010), pp. 561-569

[5] H. Yamada, M. Kobayashi. Biosci. Biotechnol. Biochem., 60 (1996), pp. 1391-1400

[6] H. Yamada, S. Shimizu, M. Kobayashi. Chem. Rec., 1 (2001), pp. 152-161

[7] R.A. Sheldon. Adv. Synth. Catal., 349 (2007), pp. 1289-1307

[8] I. Přepechalová, L. Martínková, A. Stolz, M. Ovesná, K. Bezouška, J. Kopecký, V. Křen. Appl. Microbiol. Biotechnol., 55 (2001), pp. 150-156

[9] A.L. Serdakowski, J.S. Dordick. Trends Biotechnol., 26 (2008), pp. 48-54

[10] D. Avnir, C. Thibaud, L. Ovadia, J. Livage. J. Mater. Chem., 16 (2006), pp. 1013-1030

[11] I. Gill. Chem. Matter, 13 (2001), pp. 3403-3421

[12] B.C. Dave, B. Dunn, J.S. Valentine, J.I. Zink. Anal. Chem., 66 (1994), p. 1120A

[13] B. Dunn, J.M. Miller, B.C. Dave, J.S. Valentine, J.I. Zink. Acta Mater., 46 (1998), p. 737

[14] L.M. Ellerby, C.R. Nishida, F. Nishida, S.A. Yamanaka, B. Dunn, J.S. Valentine, J.I. Zink. Science, 255 (1992), pp. $1113-1115$

[15] K. Smith, N.J. Silvernail, K.R. Rodgers, T.E. Elgren, M. Castro, R.M. Parker. J. Am. Chem. Soc., 124 (2002), pp. 4247-4252

[16] Y. Wei, J. Xu, Q. Feng, M. Lin, H. Dong, W.J. Zhang, C. Wang. J. Nanosci. Nanotechnol., 1 (2001), pp. 83-93

[17] D.K. Eggers, J.S. Valentine. Protein Sci., 10 (2001), pp. 250-261

[18] D.J. Blyth, J.W. Aylott, D.J. Richardson, D.A. Russell. Analyst, 120 (1995), p. 2725

[19] E.H. Lan, B.C. Dave, J.M. Fukuto, B. Dunn, J.I. Zink, J.S. Valentine. J. Mater. Chem., 9 (1999), p. 45

[20] T.E. Elgren, O.A. Zadvorny, E. Brecht, T. Douglas, N.A. Zorin, M.J. Maroney, J.W. Peters. Nano Lett., 5 (2005), pp. 2085-2087

[21] M. Frampton, A. Vawda, J. Fletcher, P.M. Zelisko. Chem. Commun. (2008), pp. 5544-5546

[22] I. Pastor, M. Prieto, C.R. Mateo. J. Phys. Chem. B, 112 (2008), pp. 15021-15028

[23] M.R.N. Monton, E.M. Forsberg, J.D. Brennan. Chem. Mater., 24 (2012), pp. 796-811

[24] J.-S. Gong, Z.-M. Lu, H. Li, J.-S. Shi, Z.-M. Zhou, Z.-H. Xu. Microb. Cell Fact., 11 (2012), p. 142

[25]. J.M. Woodley. Biochem. Soc. Trans., 34 (2006), pp. 301-303

[26] A. Miyanaga, S. Fushinobu, K. Ito, T. Wakagi. Biochem. Biophys. Res. Commun., 288 (2001), pp. 1169-1174

[27] S. Mitra, R.C. Holz. J. Biol. Chem., 282 (2007), pp. 7397-7404

[28] A. Miyanaga, S. Fushinobu, K. Ito, H. Shoun, T. Wakagi. Eur. J. Biochem., 271 (2004), pp. 429-438

[29] T. Yamaki, T. Oikawa, K. Ito, T. Nakamura. J. Ferment. Bioeng., 83 (1997), pp. 474-477

[30] E. Gasteiger, C. Hoogland, A. Gattiker, S.E. Duvaud, M. Wilkins, R. Appel, A. Bairoch. J. Walker (Ed.), The Proteomics Protocols Handbook, Humana Press, Totowa, NJ (2005), pp. 571-607

[31] A.C. Pierre. Biocatal. Biotransform., 22 (2004), pp. 145-170

[32] V.B. Kandimalla, V.S. Tripathi, H. Ju. Crit. Rev. Anal. Chem., 36 (2006), pp. 73-106

[33] U.T. Bornscheuer. Angew. Chem. Int. Ed., 42 (2003), pp. 3336-3337 